\title{
DETECTION OF PATHOGENIC LEPTOSPIRA SPP. IN GOATS FROM SLAUGHTERHOUSES IN SOUTHWESTERN NIGERIA USING ISOLATION, HISTOCHEMISTRY AND IMMUNOHISTOCHEMISTRY
}

\author{
Olusola Lawrence Ajayi ${ }^{1}$, Edem Richard Antia ${ }^{2}$, Ojebiyi Oluwabusayo Esther ${ }^{1}$, \\ Temitope Morenikeji Oladipo ${ }^{1}$, Olajire Moshood Olaniyi ${ }^{1}$, Olajoju Jokotola Awoyomi ${ }^{3}$ \\ ${ }^{1}$ Department of Veterinary Pathology, \\ Federal University of Agriculture, Abeokuta, Ogun State, Nigeria \\ ${ }^{2}$ Department of Veterinary Pathology, University of Ibadan, Ibadan, Nigeria \\ ${ }^{3}$ Department of Public Health and Preventive Medicine, \\ Federal University of Agriculture, Abeokuta, Ogun State, Nigeria
}

Received 21 February 2020; Received in revised form 23 August 2020; Accepted 15 September 2020

\begin{abstract}
Studies on caprine leptospirosis using isolation, histochemistry and immunohistochemistry are rare. The role of small ruminants in the epidemiology of leptospirosis is scarce. This study investigated the prevalence of Leptospira spp. serovars, and the renal pathology of caprine leptospirosis in slaughterhouses from two states in southwest Nigeria using isolation (IS), Warthin Starry silver (WSs) impregnation and immunohistochemistry (IH). One hundred and sixty-nine kidney samples were randomly obtained from goats between September 2015 and June 2017. Chi-square test was used with a confidence level set at 0.05 to ascertain associations between the positive cases, sex and animal species. Eightyseven (51.5\%) samples were positive on IS, out of which $26 / 40$ and $25 / 30$ were positive on WSs and IH, respectively. Ten $(5.9 \%)$ kidneys showed macroscopic lesions while interstitial nephritis $(48.6 \%)$ and tubular nephrosis $(64.2 \%)$ were the most prominent histopathological changes. The most frequently observed positive reactions were against serovars Hardjo type Prajitno (12/25, 48\%), and Gripptotyphosa (5/25, 20\%). Other serovars such as Bratislava $(2 / 25,8 \%)$, Canicola $(3 / 25,12 \%)$, Icterohaemorrhagiae $(2 / 25,8 \%)$, and Pomona $(1 / 25,4.0 \%)$ were also detected using IH. The result showed high prevalence of Leptospira infection in goats and the possibility of humans contracting the disease. To date, the detection of leptospirosis from kidneys of goats using IS, WSs and IH has not been reported. This study is the first documentation of evidence of pathogenic Leptospira species in renal tissues of goats.
\end{abstract}

Key words: goats, kidney, leptospirosis, culture isolation, histopathology, immunohistochemistry

\section{INTRODUCTION}

The importance of goats in the sub-Sahara livestock industry cannot be underestimated (1). It represents about $48.9 \%$ of the total grazing livestock in Nigeria (2). In Nigerian society, goats are raised for their meat, milk, hair and skin. They also serve as

Corresponding author: Dr. Olusola Lawrence Ajayi, $\mathrm{PhD}$

E-mail address: alabsola@yahoo.com

Present address: Department of Veterinary Pathology, Federal University of Agriculture, Abeokuta, Ogun State, Nigeria

Phone: +2348068783895

Copyright: (C) 2020 Ajayi O.L. This is an open-access article published under the terms of the Creative Commons Attribution License which permits unrestricted use, distribution, and reproduction in any medium, provided the original author and source are credited

Competing Interests: The authors have declared that no competing interests exist.

Available Online First: 5 November 2020

Published on: 15 March 2021

https://doi.org/10.2478/macvetrev-2020-003 a flexible financial reserve for the rural population as well as for the socio-cultural customs and traditions of the people (1). In tropical regions, goat farming is a long and common household practice where animals feed on kitchen wastes, scavenging, and bush grazing resulting in low productivity and high rate of disease incidence (3).

In southwest Nigeria, goat production systems are free-roaming, tethering and confined. Goats are bred by a large number of rural households, more frequently as free-roaming village flocks and more rarely in pens. Usually, individuals have two to four animals of which two or three are shegoats, depending on the number of available bucks for reproductive activities (4). Over the years, in the humid region of sub-Saharan Africa, diseases have been the major constraint in small ruminant 
production, especially peste des petits ruminants (PPR) (5). Regrettably, the impact of other diseases like leptospirosis has not been fully investigated.

Leptospirosis has been adjudged to be one of the most widespread diseases worldwide (6). But the impact of the disease is uncertain especially in many developing countries of the world. The prevalence of animal infection across the world, estimated by serological analysis, is between $2 \%$ to $46 \%$, depending on the animal species (7). The disease is of major economic concern when it involves a reproductive failure in food-producing animals (8). In Brazil, it was described as the most frequent infection with a high potential of impairing productivity in small ruminants (9). Leptospirosis mimics other infectious diseases including brucellosis, trypanosomosis, influenza, Q-fever, ehrlichiosis and anaplasmosis (10). This has led to misdiagnosis and under-reporting of the disease in a flock or herd of small ruminants $(11,12)$. The epidemiology of leptospirosis in goats is uncertain, but it is possible that goats could serve as a source of infection to humans since they live in close proximity with their owners (13). The disease usually produces subtle and subclinical infections in goat herds. Acute infection is rarely observed in adult goats but the subclinical infection is mainly characterized by clinical manifestations such as decreased milk production, abortions, low fertility, weak kids $(14,15)$, as well as non-reproductive manifestations such as septicemia, nephritis and death (16). In the pathogenesis of leptospirosis, the kidney has always been one of the 'preferred' target organs in both acute and chronic infections. The acute injury is as a result of tubulointerstitial nephritis (17). A previous study in southwest Nigeria on leptospirosis in sheep and goats more than seventeen years ago indicated a seroprevalence of $13.1 \%$ (13). There is a paucity of information on the prevalence of caprine leptospirosis and the associated serovars, as well as the renal pathology in Nigeria due to the insufficient employment of improved diagnostic methods. Studies on caprine leptospirosis using culture isolation, histochemistry and immunohistochemistry are rare. Therefore, this study was designed to determine the prevalence of caprine leptospirosis, associated serovars, and the renal pathology in slaughterhouses from two states in the southwest Nigeria employing culture-isolation (IS), Warthin Starry silver impregnation (WSs) and immunohistochemistry (IH).

\section{MATERIAL AND METHODS}

\section{Study location}

The study was carried out in southwest Nigeria. The area consists of three local government areas within two neighboring states (Oyo and Ogun)

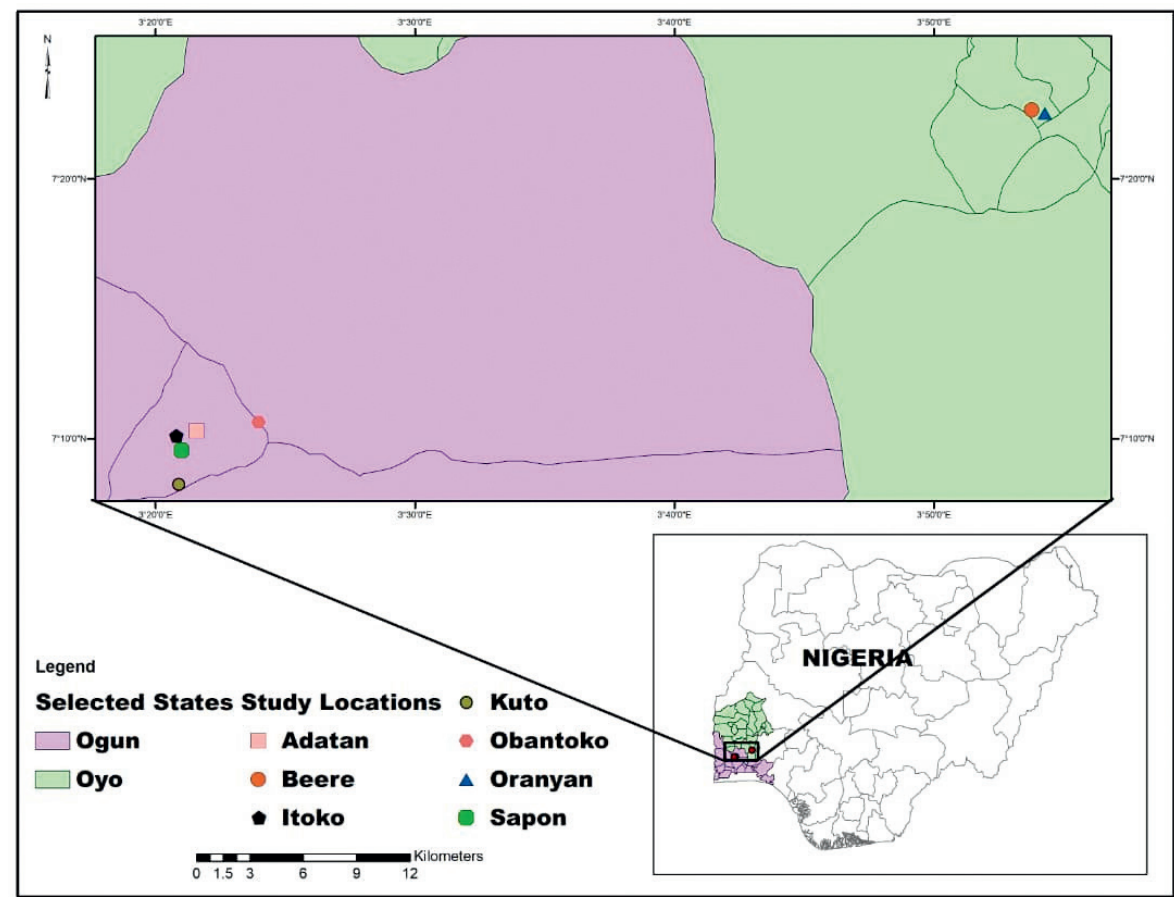

Figure 1. Map of the study area showing locations of sample collection 
characterized by a humid tropical climate with two distinct seasons; a long rainy season (March to November) and a short dry season (December to February). This study was carried out within the cities of Ibadan and Abeokuta, the capitals of Oyo and Ogun States, respectively (Fig. 1).

The city of Ibadan is located on the latitude of $7^{\circ} 23^{\prime} 47^{\prime} \mathrm{N}$, and longitude of $3^{\circ} 55^{\prime} 0^{\prime}$ ' $\mathrm{E}$ with a mean total rainfall of $1420.06 \mathrm{~mm}^{3}$, mean temperature of $23.94{ }^{\circ} \mathrm{C}$ and relative humidity of $74.55 \%$, with a population of over 4 million people. The city of Abeokuta is located on the latitude of $7^{\circ} 9^{\prime} 39^{\prime \prime} \mathrm{N}$ and longitude of $3^{\circ} 20^{\prime} 54^{\prime \prime} \mathrm{E}$, with a mean annual rainfall of $1037.00 \mathrm{~mm}^{3}$, a relative humidity of $82 \%$ and mean of $30{ }^{\circ} \mathrm{C}$. The population of Abeokuta and its environs is approximately 1 million people.

\section{Data source}

This study was conducted on goats raised and managed by indigenous people of Beere and Oranyan in Ibadan southeast local government of Oyo state and the surrounding towns and villages, while those from Ogun-state were from Obantoko, Adatan, Kuto, Sapon and Itoko in Odeda, and Abeokuta south local government areas (Fig. 1). West Africa dwarf (WAD) goats are kept by a large number of rural households as free-roaming village flocks, while the Red Sokoto were from the Northern parts of the country. The ownership pattern for the WAD is usually 2-4 animals per individual (4). The kidney samples were obtained from various slaughter slabs within the cities of Ibadan and Abeokuta.

\section{Sample size determination}

The sample size was calculated with an estimation of the predicted prevalence of $13 \%$ having an accuracy of $5 \%$ at a $95 \%$ confidence interval. The calculations were made as described by Cannon and Roe (18).

$\mathrm{N}=1.96^{2} \mathrm{P}_{\exp }\left(1-\mathrm{P}_{\exp }\right) / \mathrm{d}^{2}$

Where $\mathrm{N}=$ sample size required

$\mathrm{P}_{\exp }=$ predicted prevalence

$\mathrm{D}=$ desired precision $(5 \%)$

$1.96=$ constant for stratified and simple random samplings

\section{Sample collection}

A total of 169 kidney samples were randomly obtained from goats slaughtered in these slaughter houses. One hundred and thirteen $(n=113)$ kidney samples were obtained from the slaughter slabs at Oranyan in Ibadan, and 56 kidney samples were obtained from Obantoko, Adatan, Kuto, Sapon and Itoko slaughter slabs in Abeokuta, Ogun State. The samples were collected between September 2015 and June 2017. Parameters such as breed, sex and age were recorded. The approximate age of the animals was determined by the dentition. The samples were placed in sterile polythene bags and put into ice packs and transported to the Department of Veterinary Pathology, Federal University of Agriculture, Abeokuta within 3 to 4 hours of collection for subsequent bacteriological and pathological analyses.

\section{Culture isolation and culture medium}

Ellinghausen-McCullough-Johnson-Harris broth medium (EMJH) (Difco®-USA) with the addition of $10 \%$ filtered rabbit's serum $(0.2 \mu \mathrm{M}$ sterile filter $)$, magnesium chloride $(1 \mathrm{ml})$ and calcium chloride $(1 \mathrm{ml})$ was used for isolation of the organisms (19, 20). Nalidixic acid (50 mg/L; Inlab®-BR), neomycin (10 mg/L; Sigma $\left.{ }^{\circledR}-U S A\right)$ chloramphenicol $(5 \mathrm{mg} / \mathrm{L}$; Sigma $\left.{ }^{\circledR}-U S A\right)$ and 5-fluorouracil (400 $\mathrm{mg} / \mathrm{L}$; Sigma $\left.{ }^{\circledR}-U S A\right)$ was added to prevent the growth of contaminating bacteria.

\section{Leptospira isolation}

The isolation of Leptospira was performed by maceration of about $0.2-0.3 \mathrm{~g}$ of kidney in 2-3 ml of Phosphate Buffer Solution (PBS) with toothed forceps. This was allowed to stay for 10-15 minutes to allow the Leptospira organism to move out of the tubules. Direct inoculation of four to five drops of the macerate into $5 \mathrm{ml}$ of EllinghausenMcCullough-Johnson-Harris broth medium (EMJH) (Difco ${ }^{\circledR}-$ USA) was performed. The inoculated EMJH medium was incubated at room temperature $\left(28-30{ }^{\circ} \mathrm{C}\right)$ in the dark and examined under darkfield illumination daily and weekly for the growth of the organism for three months (21).

\section{Pathological evaluations}

The 169 kidneys were macroscopically examined and processed for histopathological examination. Paraffinized tissues were routinely stained with Hematoxylin and Eosin. Forty $(n=40)$ kidneys out of the eighty-seven $(n=87)$ culture-positive samples for Leptospira in the EMJH medium were selected for Warthin Starry silver (WSs) impregnation technique (22). The presence or absence of histopathological changes was scored as positive $(+)$ or negative $(-)$, respectively. The severity of the histological lesions such as tubular degeneration and necrosis (TDN), interstitial nephritis (IN), tubular dilatation (TD) 
Table 1. Reference rabbit leptospiral antisera used for the immunohistochemistry

\begin{tabular}{lll}
\hline Serogroup & Serovar & Strain \\
\hline Canicola & Canicola & Hond Utrecht IV \\
Icterohaemorrhagiae & Icterohaemorrhagiae & RGA \\
Pomona & Pomona & Pomona \\
Gripptotyphosa & Gripptotyphosa & Moskva V \\
Sejroe & Hardjo type Prajitno & Hardjoprajitno \\
Australis & Bratislava & Jez Bratislava \\
\hline
\end{tabular}

and hyaline cast (HC) were graded and scored as follows: 1 = mild (a focal area on section examined), $2=$ moderate (3-4 foci on section examined), $3=$ severe $(>5$ foci on the lesion examined).

\section{Immunohistochemistry}

Out of 40 kidney samples used for WSs technique, 30 were subjected to $\mathrm{IH}$ to determine the serovar and exact location of Leptospira antigen within the renal parenchyma. The six serovars of rabbit monoclonal antibodies used for immunohistochemical detection were Hardjo type Prajitno, Canicola, Grippotyphosa, Bratislava, Pomona and Icterohaemorrhagiae (Table 1). The rabbit immune sera-cocktail (Table 1) used as primary monoclonal antibodies against Leptospira antigens in the kidney sections were acquired (WHO/FAO/OIE and National Leptospirosis Reference Centre, KIT Biomedical Research, Amsterdam, The Netherlands). Serial $5 \mu \mathrm{M}$ sections from each paraffin block were mounted on slides and allowed to dry overnight. The sections were deparaffinized in 3 changes of xylene for $3 \mathrm{~min}$ each, rehydrated in a graded series of ethanol solutions $(100 \%, 95 \%$, $70 \%, 50 \% \mathrm{v} / \mathrm{v})$, and finally washed with deionized water. The deparaffinized sections were then placed in a Coplin-jar containing $0.01 \mathrm{M}$ sodium citrate buffer ( $\mathrm{pH}$ 6.0) and heated for 40-min periods, followed by cooling to room temperature for 20 minutes, to unmask the Leptospira antigens. Following 5 minutes of washing in $0.05 \mathrm{M}$ Phosphate-buffered saline solution ( $\mathrm{pH}$ 7.6) containing $0.05 \%$ Tween 20 (TPBS). All steps were performed at room temperature. The sections were first incubated in 3\% hydrogen peroxide for $15 \mathrm{~min}$ to suppress endogenous peroxidase. After a brief wash in TPBS, nonspecific binding was blocked by bathing in normal goat serum for $10 \mathrm{~min}$.

The tissues were then incubated with rabbit Leptospira monoclonal (1:800 dilution in PBS) antibodies (serovars Pomona, Bratislava,
Icterohaemorrhagiae, Hardjo, Canicola, Gripptotyphosa) overnight. After a brief wash in TPBS, the slides were incubated with biotinylated secondary antibody (goat anti-rabbit $\mathrm{IgG}$ ) for $15 \mathrm{~min}$. After the last wash in TPBS, the slides were incubated with streptavidin-biotin-horseradish peroxidase for 15 min. Slides were then rinsed with distilled water and incubated with chromogen for $10 \mathrm{~min}$. Slides were finally rinsed with distilled water to stop the staining process. Sections were counterstained with Mayer's hematoxylin for $3 \mathrm{~min}$ followed by a 5-minutes rinse in running tap water and were mounted with glycerol water-soluble mounting medium for microscopic evaluation. Negative controls were slides from Leptospira-infected tissues that were subjected to the same staining procedure as the others except that normal rabbit serum was used in place of the monoclonal antibody.

\section{Statistical analysis}

Data were presented using descriptive statistics. Effects of age, breed, sex and location were determined using Chi square. $\mathrm{P}$ value $<0.05$ was considered significant. Statistical analysis was performed using Statistical Package for Social Sciences (SPSS).

\section{RESULTS}

The overall prevalence of caprine leptospirosis from the study area was $51.5 \%(87 / 169)$. Out of the 56 kidney samples obtained from Abeokuta, 29 (51.8\%) were positive for Leptospira infection while 58 (51.3\%) were positive out of the 113 kidney samples obtained from Ibadan. There was no significant difference $(\mathrm{P}>0.05)$ between location and the prevalence of caprine leptospirosis. Out of the 9 kidney samples obtained from goats between 1-2 years of age, $8(88.9 \%)$ were positive for Leptospira infection while $27(44.3 \%)$ out of the 61 samples obtained from goats 
between 2-3 years were positive for leptospirosis. Out of the 99 kidney samples obtained from goats above three years, 52 (52.5\%) samples were positive for Leptospira infection. There was a significant $(\mathrm{P}<0.05)$ difference between the animals' age and the prevalence of leptospirosis. The prevalence of leptospirosis in Red Sokoto breeds was $52.0 \%$ out of the 50 samples examined, while $61(51.3 \%)$ out of 119 kidney samples from WAD goats were positive for leptospirosis. There was no significant difference $(P>0.05)$ between goat breed and the prevalence of leptospirosis. Out of the 79 kidney samples from male goats, 39 (49.4\%) were positive for leptospirosis, while $48(53.3 \%)$ were positive out of the 90 kidney samples from female goats. There was no significant difference $(\mathrm{P}>0.05)$ between sex and the prevalence of Leptospira infection (Fig. 2) (Table 2).

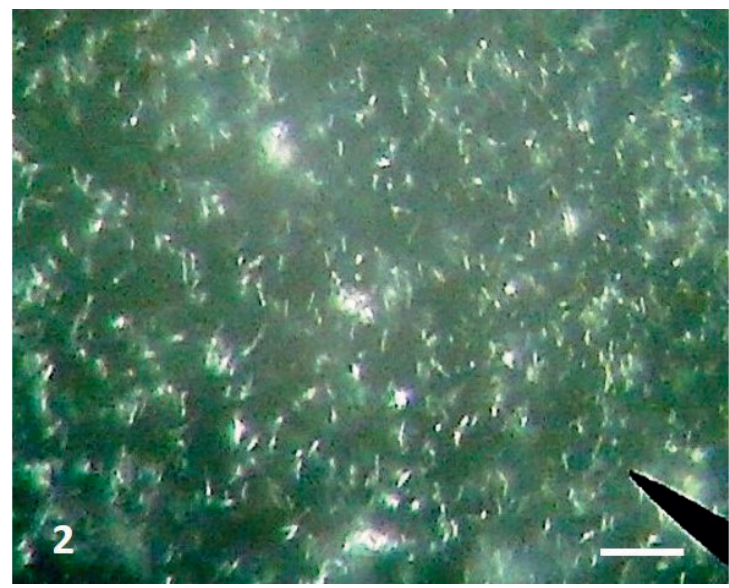

Figure 2. Photomicrograph of cultured Leptospira organism. Dark field microscopy; $\mathrm{x} 400$, Bar $=100 \mu \mathrm{m}$

\section{Macroscopic lesions}

Out of the 169 kidney samples obtained, only 10 (5.9\%) revealed gross morphological changes. The type, severity and distribution of the changes are depicted in Table 3. Out of the 10 kidney samples with gross morphological alterations, 4 had focal to multiple foci of mild cortical petechial bleeding, 3 had multiple foci of pale necrotic areas and 3 showed mild to moderate rough pitted cortical surfaces. The remaining 159 kidney samples showed no gross lesions.

\section{Renal histopathology}

The histological lesions observed in the kidneys were interstitial nephritis (characterized by interstitial, peri-glomerular and perivascular lymphoplasmacytic infiltrates) (Fig. 3a), tubular necrosis, protein casts (Fig. 3b), hemorrhages, multiple foci of interstitial fibrosis $(6.2 \%)$, tubular dilatation $(21.0 \%)$, tubular calcification $(7.0 \%)$, and tubular atrophy (16.9\%). Tubular epithelial necrosis $(64.2 \%)$ and interstitial nephritis (48.6\%) were the most frequent histological lesions observed (Table 3).

Tubular necrosis, tubular dilatation, and protein casts were mild to marked in severity while the degree of interstitial nephritis was only mild to moderate. Out of the 40 SI-positive kidney sections subjected to WSss, $26(65 \%)$ demonstrated the presence of the organism. Leptospira were slightly brown to deep brown (Fig 4a) and in some instances appeared as a black thread (Fig 4b) or dots within the tubular lumen or closely attached to the apical portion of the tubular epithelial cells.

Table 2. Risk factors associated with Leptospirosis in goats from the slaughter slabs

\begin{tabular}{|c|c|c|c|c|c|}
\hline Risk factor & & No sampled & No+ve* & Prevalence (\%) & $\begin{array}{c}\text { Chi square } \\
(\mathrm{P}<0.05)\end{array}$ \\
\hline \multirow{2}{*}{ Location } & Abeokuta & 56 & 29 & 51.8 & \multirow[b]{2}{*}{0.95} \\
\hline & Ibadan & 113 & 58 & 51.3 & \\
\hline \multirow{3}{*}{ Age } & 1-2 years & 9 & 8 & 88.9 & \multirow{3}{*}{0.03} \\
\hline & 2-3 years & 61 & 27 & 44.3 & \\
\hline & $>3$ years & 99 & 52 & 52.5 & \\
\hline \multirow{2}{*}{ Breed } & Sokoto red & 50 & 26 & 52.0 & \multirow[b]{2}{*}{0.95} \\
\hline & WAD & 119 & 61 & 51.3 & \\
\hline \multirow{2}{*}{ Sex } & Male & 79 & 39 & 49.4 & \multirow[b]{2}{*}{0.60} \\
\hline & Female & 90 & 48 & 53.3 & \\
\hline
\end{tabular}

$* \mathrm{No}+\mathrm{ve}=$ Number positive 

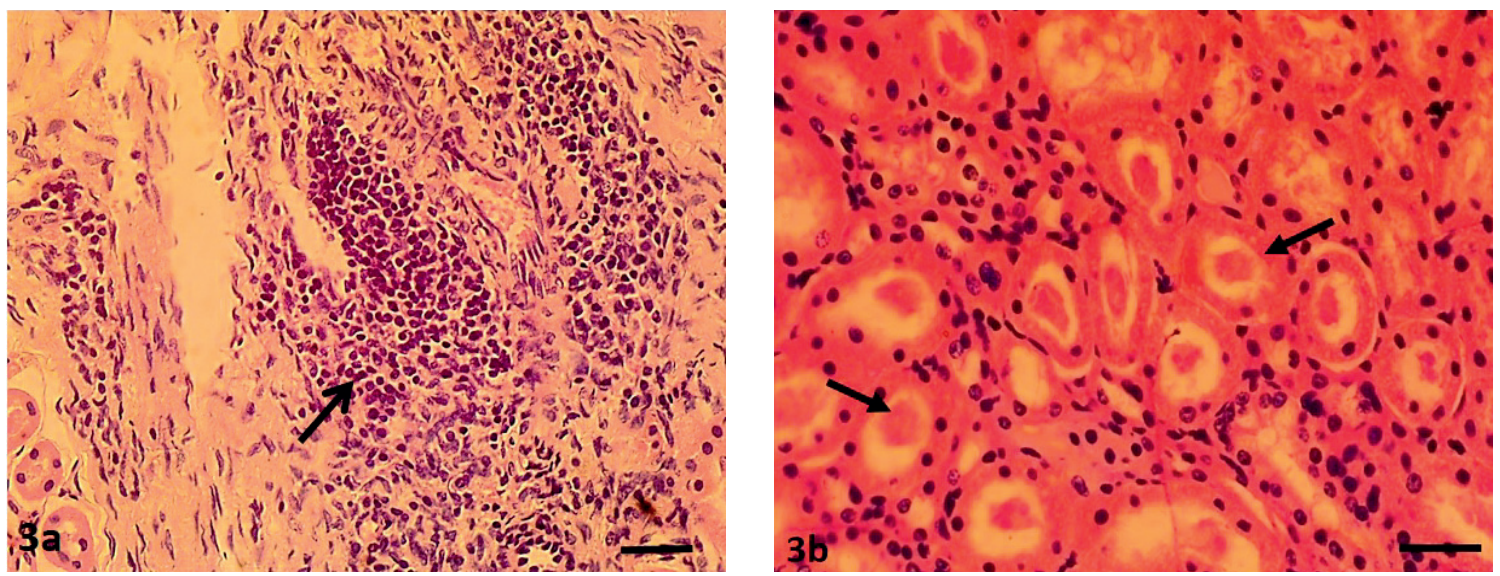

Figures 3a and 3b. Kidney showing severe tubular degeneration and necrosis, tubular atrophy and effacement due to marked focal interstitial and perivascular mononuclear cellular infiltration (a) and showing diffuse tubular degeneration and necrosis with protein casts within the tubular lumina (b). H\&E; x400, Bar=120 $\mu$ m
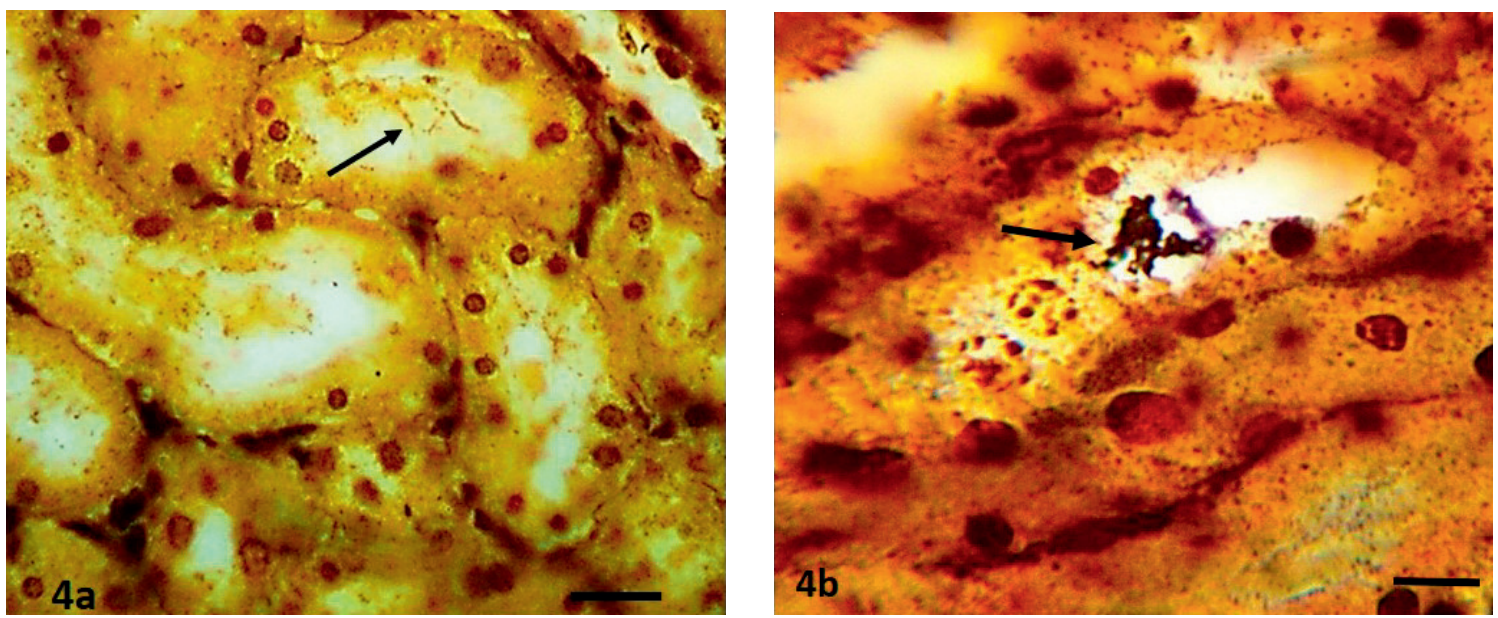

Figures $4 \mathbf{a}$ and $\mathbf{4 b}$. Kidney sections showing the presence of Leptospira organisms within tubular lumina (arrows). Warthin Starry silver; $x 400, \mathrm{Bar}=150 \mu \mathrm{m}$ (a), $75 \mu \mathrm{m}$ (b)

\section{Immunohistochemical evaluation}

Out of the 30 kidney samples positive on IS for Leptospira and analyzed on IH, only 25 (83.3\%) samples were immunoreactive (Table 3). Out of the 25 positive samples, $12(48 \%)$ were immunoreactive to serovar Hardjo type Prajitno (Fig. 5a and b), 5 (20\%) for Gripptotyphosa, 3 (12\%) for Canicola (Fig. 5c), 2 (8\%) each for serovar Bratislava and Icterohaemorrhagiae, and $1(4 \%)$ for serovar Pomona.

The positive immunoreactivity was observed either closely confined within the tubular lumina or on the apical surfaces of the tubular epithelial cells, and was not observed in the adjacent peritubular tissues and interstitium. Wavy and dot-like appearance was observed within the renal tubular lumina. Twenty kidney sections which were positive on IS and WSs also showed foci of immunoreactivity with at least one monoclonal antibody (Table 3). Five kidney sections were WSs-negative but were positive on IS and IH (Table 3).

Three kidney sections were positive on IS, but negative on WSs and IH, and two were IS and WSs positive but IH negative. Immunoreactivity was restricted to the proximal distal convoluted tubules and collecting ducts. Renal sections without specific monoclonal antibody were negative (Fig. 5d). 

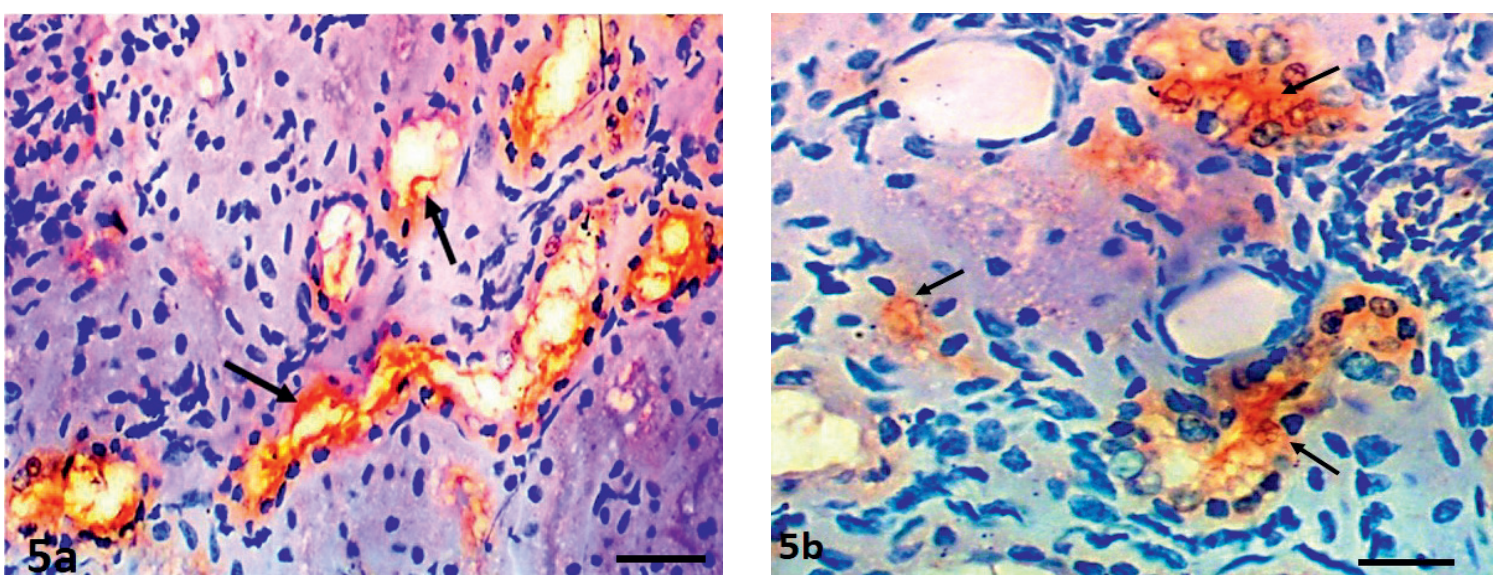

Figures 5a and 5b. Kidney sections showing Leptospira Hardjo colonization of the collecting tubules (arrows) and

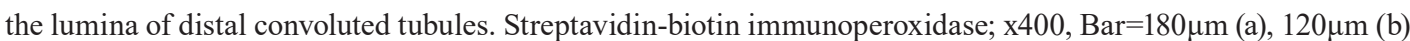

Table 3. Summary of gross morphological changes, culture isolation, histopathological changes and immunohistochemistry from 30 kidney samples of goats with Leptospira infection

\begin{tabular}{|c|c|c|c|c|c|c|c|c|c|c|c|c|c|}
\hline \multirow[t]{2}{*}{$\mathbf{S} / \mathbf{N}$} & \multirow[t]{2}{*}{$\begin{array}{l}\text { Renal gross morphological } \\
\text { changes (severity) }\end{array}$} & \multirow[t]{2}{*}{ CI } & \multicolumn{4}{|c|}{$\begin{array}{l}\text { Histopathological Changes } \\
\text { (Severity) }\end{array}$} & \multirow{2}{*}{$\begin{array}{c}\text { WSss } \\
+/-\end{array}$} & \multicolumn{6}{|c|}{ Immunohistochemistry (IH) } \\
\hline & & & TDN & IN & TD & $\mathrm{HC}$ & & LH & LC & LB & LI & $\mathbf{L P}$ & LG \\
\hline 1 & - & + & $+(1)$ & - & $+(1)$ & - & + & + & - & - & - & - & - \\
\hline 2 & - & + & $+(1)$ & - & $+(2)$ & - & + & + & - & - & - & - & - \\
\hline 3 & - & + & $+(1)$ & - & $+(1)$ & - & + & - & - & - & - & + & - \\
\hline 4 & Foci of cortical petechiation (2) & + & $+(2)$ & $+(1)$ & - & - & + & - & - & - & + & - & - \\
\hline 5 & - & + & $+(1)$ & $+(1)$ & - & - & + & + & - & - & - & - & - \\
\hline 6 & - & + & $+(1)$ & $+(1)$ & - & $+(2)$ & + & - & - & + & - & - & - \\
\hline 7 & - & + & $+(1)$ & $+(1)$ & - & - & + & + & - & - & - & - & - \\
\hline 8 & $\begin{array}{l}\text { Focal area of cortical } \\
\text { petechiation (1) }\end{array}$ & + & $+(1)$ & $+(1)$ & - & - & + & - & - & - & - & - & + \\
\hline 9 & - & + & $+(1)$ & - & $+(1)$ & - & + & + & - & - & - & - & - \\
\hline 10 & Multifocal paleness (2) & + & $+(3)$ & - & - & $+(2)$ & - & - & - & - & - & - & - \\
\hline 11 & - & + & $+(1)$ & - & $+(1)$ & - & - & + & - & - & - & nd & - \\
\hline 12 & - & + & $+(1)$ & - & $+(1)$ & - & + & + & - & - & - & - & - \\
\hline 13 & Foci of cortical petechiation (1) & + & $+(1)$ & - & $+(1)$ & $+(1)$ & + & - & - & - & - & - & - \\
\hline 14 & - & + & $+(3)$ & $+(1)$ & - & - & + & - & + & - & - & - & - \\
\hline 15 & Rough pitted cortex (2) & + & $+(1)$ & $+(2)$ & - & $+(1)$ & + & - & - & - & - & - & + \\
\hline 16 & - & + & $+(2)$ & $+(1)$ & - & - & + & + & - & - & - & - & \\
\hline 17 & Foci of cortical petechiation (1) & + & $+(1)$ & - & $+(2)$ & - & - & - & - & - & - & - & + \\
\hline 18 & - & + & $+(2)$ & $+(1)$ & - & - & - & - & - & - & - & - & - \\
\hline 19 & - & + & $+(1)$ & $+(1)$ & - & - & + & - & - & - & - & - & - \\
\hline 20 & Multifocal paleness (2) & + & $+(3)$ & $+(1)$ & $+(2)$ & - & + & - & + & - & - & - & - \\
\hline 21 & - & + & $+(1)$ & - & - & - & - & + & nd & - & - & nd & - \\
\hline 22 & - & + & $+(1)$ & $+(1)$ & - & & + & - & - & - & - & - & + \\
\hline 23 & Multifocal paleness (2) & + & $+(3)$ & $+(1)$ & $+(3)$ & $+(1)$ & + & - & - & - & + & - & - \\
\hline 24 & Rough pitted cortex (2) & + & $+(3)$ & $+(2)$ & - & $+(3)$ & + & + & - & - & - & - & - \\
\hline 25 & - & + & $+(1)$ & $+(1)$ & $+(1)$ & $+(1)$ & - & - & - & - & - & - & + \\
\hline 26 & - & + & $+(1)$ & $+(1)$ & $+(1)$ & - & + & - & + & - & - & - & - \\
\hline 27 & Rough pitted cortex (2) & + & $+(3)$ & $+(2)$ & - & $+(1)$ & + & + & - & - & - & - & - \\
\hline 28 & - & + & $+(1)$ & - & $+(1)$ & - & - & - & nd & + & - & - & - \\
\hline 29 & - & + & $+(1)$ & - & $+(1)$ & $+(1)$ & + & + & nd & - & - & - & - \\
\hline 30 & - & + & $+(1)$ & - & - & - & - & - & - & - & - & - & - \\
\hline
\end{tabular}




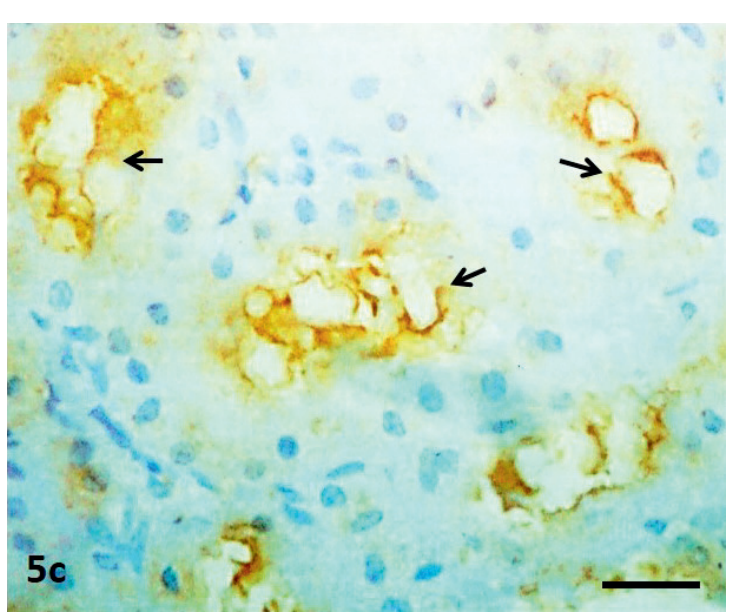

Figure 5c. Kidney sections showing Leptospira canicola colonization of the collecting tubules (arrows). Streptavidin-biotin immunoperoxidase; $x 400$, Bar $=100 \mu \mathrm{m}$

\section{DISCUSSION}

This study demonstrated Leptospira infection in goats slaughtered in the two abattoirs in southwest Nigeria. This is evidenced by the high prevalence of $51.5 \%$ of Leptospira infection using the EMJH medium when compared with a serological survey in the same area more than 17 years ago (13). In their study, $13.1 \%$ of 320 goats were serologically positive to Leptospira infection in Ibadan, Oyo state, Nigeria. The prevalence in this study was lower than that found in a previous study in the Northern part of the country, where $72.0 \%$ seroprevalence was reported (23). In countries such as Iran, Brazil, Belize and Egypt, the seroprevalence for leptospirosis in goats was found to be lower $(1.2 \%, 42.0 \%$ and $42.1 \%$ respectively) $(24,25,26)$, while in India and New Zealand was higher ( $55.2 \%$ and $70.0 \%$, respectively) $(27,28)$ than the results of our study. This might be due to variations in environmental factors such as incessant rainfall, flooding, higher environmental temperatures and host vectors which facilitate Leptospira dissemination (especially rodents) and infections (29). It is also possible that the differences in prevalence in these regions of the world might be due to variations in control and diagnostic strategies. It is noteworthy to mention that the assessment of the seroprevalence of leptospirosis in goats from these parts of the world can only suggest exposure of goats over a certain extent of time but not necessarily at the moment of sampling. The current study suggests ongoing infection which was confirmed by the isolation of Leptospira organisms

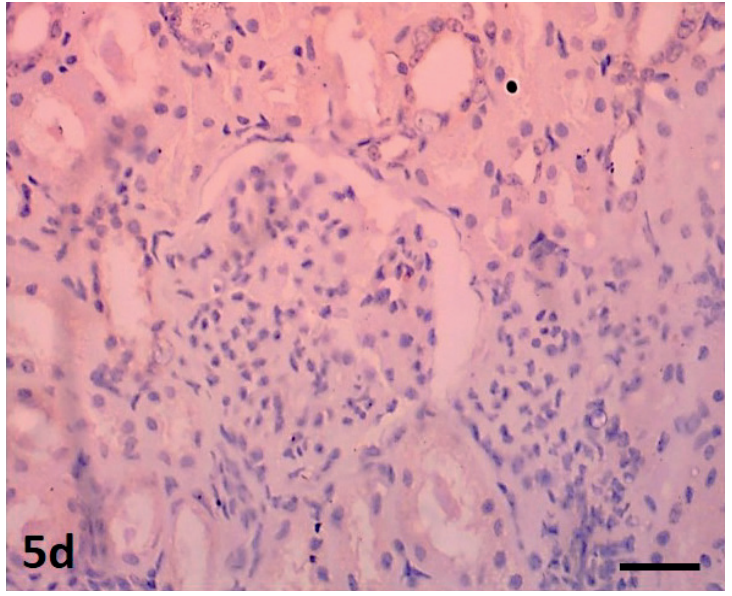

Figure 5d. Kidney section without specific monoclonal antibody showing negative immunoreactivity. Streptavidin-biotin immunoperoxidase; $\mathrm{x} 400$, Bar $=150 \mu \mathrm{m}$

from the kidney of these goats. The area of sample collection and the number of samples in this study might not be appropriate for precise determination of the leptospirosis prevalence, however, the presence of certain serovars in this region was determined. This finding will be useful to abattoirs workers, veterinary practitioners and farmers who are highly exposed to this disease with zoonotic implications. There was no significant influence of sex, breed and location of goats on the prevalence of leptospirosis, but there was a significant difference in Leptospira infection in animals between the age of 1-2 years. The high prevalence of leptospirosis in this age group might be due to a lack of immunity since goats are rarely vaccinated against leptospirosis in the study area.

The macroscopic lesions observed in this study are consistent with a previous report in cattle (28). No relationship existed between macroscopic lesions and the presence of the infection because most of the samples that showed no gross morphological changes were positive for leptospirosis by IS and IH.

The most consistent histopathological changes observed in all the goats were necrosis of tubular epithelium (67.4\%), interstitial lymphoplasmacytic infiltration (61.8\%) and protein casts (61.3\%). This is in agreement with previous studies in cattle and wild animals (29). However, Skilbeck et al (30) did not observe significant histopathological changes in the kidneys of cattle which were positive on IS.

Small ruminants have been regarded as accidental hosts of Leptospira of various serovars (31). These serovars common for most domestic 
and wild animals were not specific for the analyzed specimens (31). Several studies have shown that Leptospira infection in goats and sheep are common and that they can act as the potential disseminators of the organism into the environments $(32,33)$. However, they have been usually regarded as incidental hosts (31). In small ruminants, serovar Hardjo subtype Bovis is considered to be common (34). In this study, despite the fact that the monoclonal antibody of $L$. Hardjo subtype Bovis was not used, L. Hardjo subtype Prajitno was the most predominant serovar with a detection rate of 48\% (12/25) using IH. Previous studies have shown that serovar Hardjo subtype Prajitno has higher virulence and zoonotic implications than the serovar Hardjo subtype Bovis $(35,36)$. It is also possible that cross-reactivity between these subtypes might have occurred in this study. Grippotyhphosa (5/25, $20 \%$ ), Canicola $(3 / 25,12 \%)$, Bratislava $(2 / 25,8 \%)$, Icterohaemorrhagiae $(2 / 25,8 \%)$ and Pomona $(1 / 25$, $4 \%$ ) have consecutively lower virulence. The positive confirmation of these serovars in the study area is important for planning preventive measures for animal handlers, farmers, abattoir workers, and consumers.

The specificity and reliability of the WSs impregnation method for the detection of Leptospira in this study was low. This was confirmed by the finding of 5 kidney samples which were positive on IS and $\mathrm{IH}$, but negative on WSs impregnation (Table 3). This is in agreement with previous studies (37). Moreover, kidney sections 2 and 3 which were IS and WSs positive had negative immunoreactivity. This finding suggests that the infecting serovars were not included in monoclonal antibody cocktails. With the ongoing molecular characterization of these isolates, we believe that new serovars might be detected in this animal species.

Over the years, most of the diagnosis of leptospirosis in small ruminants has relied solely upon serological assays $(29,38)$, whereas IS, WSs and IH are rarely performed (39). The authors of this study could not find any previous work in which IH had been used as a diagnostic tool for caprine leptospirosis. To the best of our knowledge, this appears to be the first report in which IH was used to detect Leptospira antigens in the renal tissues of goats, and this greatly enhanced the specific diagnosis of the disease and the determination of the various serovars involved. IH employed in this study enabled Leptospira serovar determination, antigen detection, localization and distribution within the renal tissue. This is consistent with the findings of Rosetti et al. (21) who reported that $\mathrm{IH}$ yielded more serovar-specific positive results than other diagnostic methods, since WSs impregnation and isolation could only detect the presence of the organism without serovars' determination.

\section{CONCLUSION}

In conclusion, this study revealed a high prevalence of caprine leptospirosis in the study area (51.5\%) using EMJH medium compared with previous studies in which serology was used as the only diagnostic tool. IS and WSs proved to be useful diagnostic tools in that they revealed evidence of infection, but IH proved to be effective in identifying most of the various serovars involved in the study area. Consequently, this study would create an awareness of the zoonotic implications of caprine leptospirosis and assist policymakers to develop control strategies for the control of leptospirosis in goats and humans in this region.

\section{CONFLICT OF INTEREST}

The authors declare that there is no conflict of interest related to this article.

\section{ACKNOWLEDGEMENTS}

The authors of this manuscript would like to offer their profound gratitude to Mr. James of the Department of Veterinary Pathology, Federal University of Agriculture, Abeokuta Nigeria for his technical help. We are also indebted to Prof. Hartkreel of the Royal Tropical Institute, Amsterdam, the Netherlands who graciously offered the monoclonal antibodies used in this study.

\section{AUTHORS` CONTRIBUTIONS}

A.O.L. was the project leader, initiator and the pathologist that carried out the Warthin Starry silver stain, immunohistochemistry, read the slides and contributed immensely to the write up of the manuscript. A.R.E. was project leader as well, initiator and the pathologist that contributed to the slide reading and write up of the manuscript. O.O.E. and T.M.O. were involved in the collection of the kidney samples from different areas and laboratory works. O.M.O. was the pathologist who contributed to the slide reading and write up of the manuscript. A.O.J. did the statistical analysis and provision of figure one. 


\section{REFERENCES}

1. Gefu, J.O., Adu, I.F., Magaji, S.O. (1993). Characteristics of small holder sheep and goat management practices in south east Nigeria: Observation from Anambra State, Nigeria. J Anim Prod. 21(1-2): 127-134.

2. Lawal-Adebowale, O.A. (2012). Dynamics of ruminant livestock management in the context of the Nigerian agricultural system. In: Khalid Javed (Ed.), Livestock production. [Internet]. Intechopen science; 2012 October 24 Available from: https://www.intechopen.com/books/livestock-production/ dynamics-of-ruminant-livestock-management-in-thecontext-of-the-nigerian-agricultural-system https://doi.org/10.5772/52923

3. Gefu, J.O., Audu, I.F. (1984). Understanding small ruminant production in Northern Nigeria. World Review of Animal Production. 20(3): 35-39.

4. Opasina, B.A., David-West, K.B. (1988). Position paper on sheep and goat production in Nigeria [Internet]. Federal Livestock Department, Lagos, Nigeria. Available from:

http://www.fao.org/3/s8374b/S8374b20.htm

5. Jarikre, A.T.A., Emikpe, B.O. (2017). First report of immunohistochemical detection of peste des petit ruminants, parainfluenza 3 and respiratory syncytial viral antigens in lungs of Nigerian goats. J Immunoassay Immunochem. 38(5): 555-568. https://doi.org/10.1080/15321819.2017.1349669 PMid:28679075

6. World Health Organization. (1999). Leptospirosis worldwide. Wkly Epidemiol Rec. 74(29): 237-242.

7. Leal-Castellanos, C.B., Carcia-Suarez, R., Gonzalez-Figueroa, E., Fuentes-Allen, J.L., Escobedo-de La Rena, J. (2003). Risk factors and the prevalence of leptospirosis infection in a rural community of Chiapas, Mexico. Epidemiol Infect. 131(3): 1149-1156.

https://doi.org/10.1017/S0950268803001201

PMid:14959783 PMCid:PMC2870065

8. Bomfim, M.Q., Koury, M.C. (2006). Evaluation of LSSP-PCR for the identification of Leptospira spp. in urine samples of cattle with clinical suspicion of leptospirosis. Vet Microbiol. 118(3-4): 278-288. https://doi.org/10.1016/j.vetmic.2006.07.020 PMid:16962259

9. Martins, G., Penna, B., Hamond, C., Leite, R.C.K., Silva, A., Ferreira, A., Brandão, F., Oliveira, F., Lilenbaum, W. (2012). Leptospirosis as the most frequent infectious disease impairing productivity in small ruminants in Rio de Janeiro, Brazil. Trop Anim Health Prod. 44(4): 773-777.

https://doi.org/10.1007/s11250-011-9964-4 PMid:21898182
10. Izurieta, R., Galwankar, S., Clem, A. (2008). Leptospirosis: The "mysterious" mimic. J Emerg Trauma Shock. 1(1): 21-33.

https://doi.org/10.4103/0974-2700.40573

PMid:19561939 PMCid:PMC2700559

11. Meites, E., Jay, M.T., Deresinki, S., Shieh, W., Zaki, S.R., Tompkins, L., Smith, D. (2004). Re-emerging leptospirosis, California. Emerg Infect Dis. 10(3): 406-412.

https://doi.org/10.3201/eid1003.030431

PMid:15109405 PMCid:PMC3322787

12. Office International des Epizooties. [Internet]. Terrestrial manual. (2018). Leptospirosis. Chapter 3.1.12. pp-503-516. Available from:

https://www.oie.int/fileadmin/Home/eng/Health_ standards/tahm/3.01.12_LEPTO.pdf

13. Agunloye, C.A., Oyeyemi, M.O., Akusu, M.O., Ajala, O.O., Agbede, S.A. (2002). Clinical and serological diagnosis of leptospirosis in aborting West African dwarf goats. Bull Anim Health Prod Afr. 45, 5-8.

14. Martins, G., Brandão, F.Z., Hamond, C., Medeiros, M., Lilenbaum, W. (2012). Diagnosis and control of an outbreak of leptospirosis in goats with reproductive failure. Vet J. 193, 600-601. https://doi.org/10.1016/j.tvj1.2012.01.016 PMid:22365844

15. Grooms, D.L. (2006). Reproductive losses caused by bovine viral diarrhea and leptospirosis. Theriogenology 66(3): 624-628.

https://doi.org/10.1016/j.theriogenology.2006.04.016 PMid:16716386

16. Dhaliwal, G.S., Murray, R.D., Ellis, W.A. (1996). Reproductive performance of dairy herds infected with Leptospira interrogans serovar Hardjo relative to the year of diagnosis. Vet Rec. 138(12): 272-276. https://doi.org/10.1136/vr.138.12.272 PMid:8711883

17. Yang, C.W. (2007). Leptospirosis renal disease: Understanding the initiation by Toll- like receptors. Kidney Int. 72(8): 918-925.

https://doi.org/10.1038/sj.ki.5002393 PMid:17687261

18. Cannon, R.M., Roe, R.T. (1982). Livestock disease surveys. A field manual for veterinarians. Bureau of rural science, Department of primary industry. Australian Government Publishing Service, Canberra.

19. Ellinghausen, H.C., McCullough, W.G. (1965). Nutrition of Leptospira pomona and growth of 13 other serotypes: fractionation of oleic albumin complex and a medium of bovine albumin and polysorbate 80. Am J Vet Res. 26, 45-51. 
20. Johnson, R.C., Harris, V.G., (1967). Differentiation of pathogenic and saprophytic leptospires. I. Growth at low temperatures. J Bacteriol. 94(1): 27-31. https://doi.org/10.1128/JB.94.1.27-31.1967 PMid:6027998 PMCid:PMC251866

21. Rosetti, C., Bibiana, N.V., Noemi, P., Julio, C.C. (2004). Comparison of three diagnostic methods for the detection of leptospires in the kidneys of wild house mice (Mus musculus). Pesq Vet Bras. 24(1): 6-10. https://doi.org/10.1590/S0100-736X2004000100003

22. Warthin, A.S., Starry, A.C. (1920). A more rapid and improved method of demonstrating spirochetes in tissues. Am J Syphilis. 4, 97-103.

23. Holland, J., Parker, A.J., Heslop, C.G. (1977). The prevalence of antibodies against leptospira in goats, sheep and cattle in northern Nigeria. Final Report of the West African Research Team. (pp. 29-36). London: Royal Veterinary College.

24. Maronpot, R.R., Barsoum, I.S. (1972). Leptospiral microscopic agglutination antibodies in sera of man and domestic animals in Egypt. Am Trop Med Hyg. 21(4): 467-472.

https://doi.org/10.4269/ajtmh.1972.21.467

PMid:5065696

25. Sratname, K.L., Coreverad, A., Bsuresh, M.I., Alex, J.C. (1992). Leptospira antibodies among sheep and goat. Indian J Anim Sci. 62, 1041-1043.

26. Ciceroni, L.A., Bartoloni, A., Pinto, P., Guglielmetti, C., Vald, V.H., Barahona, M.R., Giannice, P.F. (1997). Serological survey of leptospira infection in sheep, goats and dogs in Cordillera province, Bolivia. New Microbiol. 20(1): 77- 81.

https://doi.org/10.1111/j.1439-0450.1997.tb00960.x PMid:9197208

27. Higino, S.S., Santos, F.A., Costa, D.F., Santos, S.A.B., Silva, M.L.C.R., Alves, C.J., Azevedo, S.S. (2013). Flock-level risk factors associated with leptospirosis in dairy goats in a semiarid region of Northeastern Brazil. Prev Vet Med. 109(1-2): 158-161. https://doi.org/10.1016/j.prevetmed.2012.09.005 PMid:23031326

28. Yener, Z., Keles, H. (2001). Immunoperoxidase and histopathological examinations of leptospiral nephritis in cattle. J Vet Med A. 48(7): 441-447. https://doi.org/10.1046/j.1439-0442.2001.00355.x PMid:11599681

29. Ajayi, O.L., Antia, R.E., Ojo, O.E., Awoyomi, O. J., Oyinlola, L.A., Ojebiyi O.G. (2017). Prevalence and renal pathology of pathogenic Leptospira spp. in wildlife in Abeokuta, Ogun State, Nigeria. Onderstepoort J Vet Res. 84(1): 1210.

https://doi.org/10.4102/ojvr.v84i1.1210

PMid:28397515 PMCid:PMC6238786
30. Skilbeck, N.W., Forsyth, W.M., Dohnt, M. (1988). Bovine leptospirosis: microbiological and histological findings in cattle at slaughter. Aust Vet J. 65(3): 73-75.

https://doi.org/10.1111/j.1751-0813.1988.tb07362.x PMid:3401146

31. Leon-Vizcaino, L., De Mendoza, M.H., Garrido, F. (1987). Incidence of abortions caused by leptospirosis in sheep and goats in Spain. Comp Immunol Microbiol Infect Dis. 10(2): 149-153. https://doi.org/10.1016/0147-9571(87)90009-9

32. Silva, E.F., Brod, C.S., Cerqueira, G.M., Bourscheidt, D., Seyffert, N., Queiroz, A., Santos, C.S., Ko, A.I., Dellagostin, O.A. (2007). Isolation of Leptospira noguchii from sheep. Vet Microbiol. 121(1-2): 144-149. https://doi.org/10.1016/j.vetmic.2006.11.010 PMid:17222993 PMCid:PMC1868676

33. Lilenbaum, W., Varges, R., Medeiros, L., Cordeiro, A.G., Cavalcanti, A., Souza, G.N., Richtzenhain, L., Vasconcellos, S.A. (2008). Risk factors associated with leptospirosis in dairy goats under tropical conditions in Brazil. Res Vet Sci. 84(1): 14-17. https://doi.org/10.1016/j.rvsc.2007.03.011 PMid:17543359

34. Lilenbaum, W., Ristow, P., Fráguas, S.A., Da Silva, E.D. (2007). Evaluation of a rapid slide agglutination test for the diagnosis of acute canine leptospirosis. Rev Latinoam Microbiol. 44(3-4): 124-128.

35. Salgado, M., Otto, B., Sandoval, E., Reinhardt, G., Boqvist, S. (2014). A cross sectional observational study to estimate herd level risk factors for Leptospira spp. serovars in small holder dairy cattle farms in southern Chile. BMC Vet Res. 10, 126. https://doi.org/10.1186/1746-6148-10-126 PMid:24906684 PMCid:PMC4063232

36. Salgado, M., Otto, B., Moroni, M., Sandoval, E., Reinhardt, G., Boqvist, S., Encina, C., Muñoz-Zanzi, C. (2015). Isolation of Leptospira interrogans serovar Hardjoprajitno from a calf with clinical leptospirosis in Chile. BMC Vet Res. 11, 66. https://doi.org/10.1186/s12917-015-0369-x PMid:25888965 PMCid:PMC4374366

37. Wild, C.J., Greenlee, J.J., Bolin, C.A., Barnett, J.K., Haake, D.A., Cheville, N.F. (2002). An improved immunohistochemical diagnostic technique for canine leptospirosis using antileptospiral antibodies on renal tissue. J Vet Diagn Invest. 14(1): 20-24. https://doi.org/10.1177/104063870201400105 PMid:12680639 PMCid:PMC2666280 
38. Balakrishnan, G. (2012). Seroprevalence of leptospirosis in goats in Tamil Nadu. Tamilnadu J Vet Anim Science. 8(3): 138-144.
39. Martins, G., Lilenbaum, W. (2014). Leptospirosis in sheep and goats under tropical conditions. Trop Anim Health Prod. 46(1): 11-17.

https://doi.org/10.1007/s11250-013-0480-6

PMid:24085419

Please cite this article as: Ajayi O.L., Antia E.R., Esther O.O., Oladipo T.M., Olaniyi O.M., Awoyomi O.J. Detection of pathogenic Leptospira spp. in goats from slaughterhouses in southwestern Nigeria using isolation, histochemistry and immunohistochemistry. Mac Vet Rev 2021; 44 (1): 5-16. https://doi.org/10.2478/macvetrev-2020-0031 